\title{
Purification and Characterization of Four Trypsin Inhibitors from Seeds of Okra, Abelmoschus esculentus L.
}

\author{
Fusahiro Ogata, Hiroshi Imamura, ${ }^{*}$ Kouichirou Hirayama \\ and Satoru MAKISUMI \\ Department of Chemistry, Faculty of Science, Kyushu University \\ 33, Hakozaki, Higashi-ku, Fukuoka 812, Japan \\ Received March 17, 1986
}

\begin{abstract}
Four trypsin inhibitors were isolated from seeds of okra (Abelmoschus esculentus L.) and named okra trypsin inhibitors (OTI) A, B, C, and D. The molecular weights of all the inhibitors were estimated to be about 20,000 by gel filtration on Sephadex G-100 and SDS-polyacrylamide gel electrophoresis. All of these inhibitors inhibited bovine trypsin strongly with the formation of complexes at a 1:1 molar ratio and three (OTI-A, OTI-B, and OTI-C) of them also weakly inhibited bovine chymotrypsin, but not simultaneously. Subtilisin Carlsberg, pronase, papain, and porcine pepsin were not inhibited by these inhibitors. The trypsin inhibitory activity of all four inhibitors was suppressed by treatment with 1,2-cyclohexanedione but not with 2,4,6-trinitrobenzenesulfonate, suggesting that each of the inhibitors contains an arginine residue at the reactive site.
\end{abstract}

Okra (Abelmoschus esculentus L.) is a botanical species cultivated for its pod for more than 2000 years and grows in many parts of the earth. ${ }^{1)}$ It belongs to the Malvaceae, as does cotton. In Japan, okra has been used as a vegetable for its green pods, in the fresh; raw, unmatured state, and no attempt has been made to use its seeds as a source of protein. In 1975, Karakoltsidis and Constantinides reported that the amino acid composition of whole mature seeds of okra is similar to that of soybeans, yet the protein efficiency ratio is higher for okra. ${ }^{2}$ They suggested that antinutritional factors are absent in okra seeds because of the lack of difference in the protein efficiency ratio value between heated and non-heated okra flour.

During the course of our studies on proteases and their inhibitors in plants, several protease inhibitors were detected in seeds of a variety of okra that is usually cultivated in
Japan. They inhibited both bovine trypsin and chymotrypsin which are typical digestive enzymes. Although it is uncertain whether the okra protease inhibitors are antinutrients for humans and other animals or not, the isolation of these inhibitors in pure form and the characterization of them will help in establishing their nutritional importance.

One of the major component of these okra protease inhibitors has been purified by a seven-step procedure using trypsin-Sepharose affinity chromatography as described previously. ${ }^{3)}$ In this paper, we describe the purification without the use of affinity chromatography and properties of the four trypsin inhibitors.

\section{MATERIALS AND METHODS}

Materials. One variety "Ichiban-boshi" of okra seeds was used throughout this study. Bovine trypsin [3.4.21.4]

* Present address: New Drug Research \& Development Department, Pharmaceutical Division, Tsumura Juntendo, Inc., Nihombashi-Honcho, Chuo-ku, Tokyo 103, Japan.

Abbreviations: OTI, okra trypsin inhibitor; BAPA, $N$-benzoyl-L-arginine $p$-nitroanilide; BTPA, $N$-benzoyl-Ltyrosine $p$-nitroanilide; SDS, sodium dodecyl sulfate; CHD, 1,2-cyclohexanedione; TNBS, 2,4,6-trinitrobenzenesulfonate; IU, inhibitor unit. 
and chymotrypsin [3.4.21.1] were purchased from Boehringer Mannheim. Porcine pepsin was from Worthington Biochemical Corp. Subtilisin Carlsberg was from the Sigma Chemical Co. Pronase was from Kaken Kagaku Co., Ltd. and papain was from Merck. Hammersten casein was a product of Wako Pure Chemical Industries Ltd. $N$-Benzoyl-L-arginine $p$-nitroanilide (BAPA) and $N$-benzoyl-L-tyrosine $p$-nitroanilide (BTPA) were the products of the Protein Research Foundation. Sephadex G-100 and CM-Sepharose were from Pharmacia Fine Chemicals. DEAE-cellulose (Brown) was from Nakarai Chemical Ltd. All other chemicals were of reagent grade.

Purities of trypsin and chymotrypsin. Active site titration of trypsin with $p$-nitrophenyl $p^{\prime}$-guanidinobenzoate was done by the method of Chase and Shaw, ${ }^{4)}$ and that of chymotrypsin with $p$-nitrophenyl- $N^{2}$-acetyl- $N^{1}$-benzylcarbazate was by the method of Elmore and Smith. ${ }^{\text {) }}$ By these procedures, trypsin and chymotrypsin used in this study were found to contain $56 \%$ and $95 \%$ active enzyme, respectively.

Activity assays. Inhibition of trypsin was measured by the method described previously, using BAPA as a substrate. ${ }^{6)}$ Inhibition of chymotrypsin was measured by a method based on that of $\mathrm{Kassell}^{7)}$ using BTPA as a substrate. A mixture of chymotrypsin $(50 \mu \mathrm{g})$ and inhibitor in $5.0 \mathrm{ml}$ of $0.1 \mathrm{M}$ Tris- $\mathrm{HCl}, \mathrm{pH} 8.0$, containing $0.01 \mathrm{M}$ $\mathrm{CaCl}_{2}$ was incubated for $5 \mathrm{~min}$ at $37^{\circ} \mathrm{C}$, and then $0.5 \mathrm{ml}$ of $2 \mathrm{~mm}$ BTPA in dimethylsulfoxide was added. After incubation for $30 \mathrm{~min}$ at $37^{\circ} \mathrm{C}$, one $\mathrm{ml}$ of $30 \%$ acetic acid solution was added and the absorbance of the reaction mixture at $410 \mathrm{~nm}$ was measured. One inhibitor unit (1 IU) is defined as the amount of inhibitor which suppressed the liberation of one mole of $p$-nitroaniline per min by the active emzymes.

Proteolysis by other proteases was measured by the methods of Hagihara ${ }^{8)}$ for subtilisin Carlsberg, Arnon ${ }^{9)}$ for papain, Narahashi ${ }^{10)}$ for pronase, and Tang ${ }^{11)}$ for pepsin.

Measurement of protein concentration. The concentration of protein was measured by the method of Lowry et $a l .{ }^{12)}$ with bovine serum albumin as a standard.

Polyacrylamide gel electrophoresis. Polyacrylamide gel electrophoresis was done by the method of Davis ${ }^{13)}$ in $7.5 \%$ polyacrylamide gels at $\mathrm{pH} 9.4$. Proteins were stained with $0.1 \%$ Coomassie brilliant blue G-250 in $50 \%$ trichloroacetic acid. Sodium dodecyl sulfate (SDS) polyacrylamide gel electrophoresis was done essentially by the method of Weber and Osborn ${ }^{14)}$ in $14 \%$ gels.

Measurement of molecular weights. The molecular weights of the inhibitors and the inhibitor-enzyme complexes were estimated using a Sephadex G-100 column
$(1.4 \times 90 \mathrm{~cm})$ equilibrated with $0.05 \mathrm{~m}$ Tris $-\mathrm{HCl}$ buffer, $\mathrm{pH}$ 8.0 , containing $0.05 \mathrm{M} \mathrm{NaCl}$. Standard proteins used were bovine serum albumin $(\mathrm{MW}=66,000)$, ovalbumin $(45,000)$, chymotrypsinogen $(25,000)$, and lyzozyme $(14,000)$. The void volume was identified with blue dextran.

Measurement of isoelectric points and hexose contents. Isoelectric points of the purified inhibitors were measured at $20^{\circ} \mathrm{C}$ by polyacrylamide gel electrofocusing ${ }^{15)}$ using $2 \%$ Pharmalyte of $\mathrm{pH} 3 \sim 10$. Bovine chymotrypsinogen ( $\mathrm{pI}$ 9.5), bovine hemoglobin (pI 7.6), and ovalbumin (pI 4.6) were used as standard proteins.

The hexose of the purified inhibitors were measured by the phenol-sulfuric acid method. ${ }^{16)}$

Measurement of inhibitor constants $(K i)$. The approximate $K i$ values of the inhibitor-enzyme complexes were measured by the method of Green and Work ${ }^{17)}$ at $\mathrm{pH} 8.0$, using BAPA for trypsin, and the method of Dixon ${ }^{18)}$ at pH 8.0, using BTPA for chymotrypsin.

Amino acid analysis. Protein samples $(1.0 \mathrm{mg})$ were hydrolyzed with $1.0 \mathrm{ml}$ of $6 \mathrm{M} \mathrm{HCl}$ in evacuated, sealed tubes for 24,48 , and $72 \mathrm{hr}$ at $110^{\circ} \mathrm{C}$, and analyzed with a JEOL model JLC-6AS amino acid analyzer. Cysteine was measured as cysteic acid after performic acid oxidation. ${ }^{19)}$ Tryptophan was measured spectrophotometrically. ${ }^{20)}$ The absence of free sulfhydryl groups was confirmed by the method of Ellman. ${ }^{21)}$

Identification of amino-terminal residue. The aminoterminal residue was identified by the dansylation method of Gray. ${ }^{22)}$ Dansyl-amino acids were separated by polyamide layer chromatography. ${ }^{23)}$

Chemical modification. Arginine residues in the inhibitors were modified by the method of Patthy and Smith $^{24)}$ using 1,2-cyclohexanedione (CHD). A 0.3-ml sample of $0.5 \mathrm{M} \mathrm{CHD}$ in distilled water was added to $2.7 \mathrm{ml}$ of $0.2 \mathrm{M}$ borate buffer, $\mathrm{pH} 9.0$, containing $1.2 \mathrm{mg}$ of inhibitor. After various periods of incubation at $37^{\circ} \mathrm{C}, 0.1$ $\mathrm{ml}$ samples were withdrawn and assayed for residual inhibitory activities against trypsin and chymotrypsin.

Amino groups were modified by the method of Plapp et al. ${ }^{25)}$ using 2,4,6-trinitrobenzenefulfonate (TNBS). A 0.3$\mathrm{ml}$ sample of $0.8 \%$ TNBS in distilled water was added to $3.0 \mathrm{ml}$ of $0.05 \mathrm{M}$ borate buffer, $\mathrm{pH} 9.5$, containing $1.5 \mathrm{mg}$ of inhibitor. After various periods of incubation at $25^{\circ} \mathrm{C}$ in the dark, the absorbance at $367 \mathrm{~nm}$ of the reaction mixture was measured and residual trypsin inhibitory activity was assayed. The extent of trinitrophenylation of amino groups was calculated on the basis of an $\varepsilon_{367}=$ $1.1 \times 10^{4} \mathrm{M}^{-1} \mathrm{~cm}^{-1}$. 


\section{RESULTS}

\section{Purification of the inhibitors}

All chromatography was done at room temperature.

Okra seeds $(100 \mathrm{~g})$ were homogenized in one liter of distilled water and the homogenate was filtered through cotton cloth. Cetavlon (cetyltrimethylammonium bromide) was added to the filtrate until the concentration was $0.2 \%(\mathrm{wt} / \mathrm{v})$. The mixture solution was centrifuged at $5800 \times g$ for $30 \mathrm{~min}$ to remove the resulting precipitate. The supernatant was brought to $80 \%$ saturation with solid ammonium sulfate. After standing overnight, the precipitate was collected by centrifugation at $18,000 \times g$ for $20 \mathrm{~min}$ and then it was dissolved in $0.05 \mathrm{M}$ Tris- $\mathrm{HCl}$ buffer, $\mathrm{pH}$ 8.0. The solution was dialyzed against distilled water at $4{ }^{\circ} \mathrm{C}$. After centrifugation, the supernatant was lyophilized. The lyophilized sample $(1800 \mathrm{mg})$ was dissolved in $200 \mathrm{ml}$ of $0.05 \mathrm{M}$ Tris- $\mathrm{HCl}$ buffer, $\mathrm{pH} 8.0$ and put on a DEAE-cellulose column $(2.8 \times 60 \mathrm{~cm})$ equilibrated with the same buffer. The column was washed with the same buffer and eluted with a linearly increasing concentration of $\mathrm{NaCl}$ from zero to $0.4 \mathrm{M}$ in the same buffer (Fig. 1). Two main peaks containing inhibitory activity appeared, and they were designated as peaks I and II. Peaks I and II were separately pooled, dialyzed, and lyophilized. The results of the preparation of peaks I and II are summarized in Table I.

The lyophilized sample of peak I (185 mg)

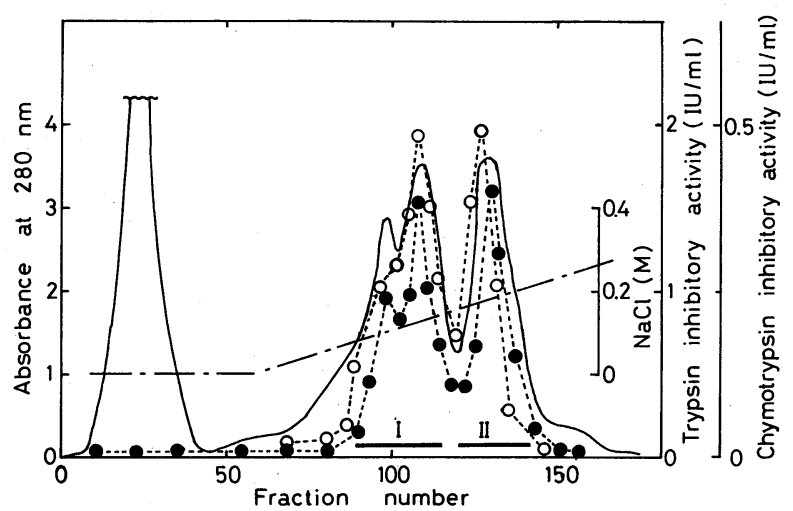

FIG. 1. DEAE-cellulose Column Chromatography of the Lyophilized Sample Obtained by Ammonium Sulfate Precipitation.

Details are described in the text. Flow rate, $40 \mathrm{ml} / \mathrm{hr}$ and fraction volume, $10 \mathrm{ml} ;-$, absorbance at $280 \mathrm{~nm}$; ------, trypsin inhibitory activity; --- $\bigcirc---$, chymotrypsin inhibitory activity; --- , $\mathrm{NaCl}$ concentration.

Table I. Purification of Peak I and Peak II from Seeds of OKra

\begin{tabular}{|c|c|c|c|c|c|}
\hline \multirow{2}{*}{ Step } & \multirow{2}{*}{$\begin{array}{l}\text { Total protein } \\
(\mathrm{mg})\end{array}$} & \multicolumn{2}{|c|}{ Total activity (IU) ${ }^{c}$} & \multicolumn{2}{|c|}{ Recovery $(\%)$} \\
\hline & & $\mathrm{T}^{a}$ & $\mathrm{CT}^{b}$ & $\mathrm{~T}^{a}$ & $\mathrm{CT}^{b}$ \\
\hline Extraction & 9640 & 1370 & 252 & 100 & 100 \\
\hline Cetavlon treatment & 3290 & 1250 & 173 & 91 & 67 \\
\hline$\left(\mathrm{NH}_{4}\right)_{2} \mathrm{SO}_{4}$ precipitation & 1890 & 838 & 110 & 61 & 44 \\
\hline DEAE-cellulose Peak I & 662 & 622 & 87 & 45 & 35 \\
\hline Peak II & 510 & 366 & 53 & 27 & 21 \\
\hline
\end{tabular}

a $\mathbf{T}$, trypsin inhibitory activity.

b CT, chymotrypsin inhibitory activity.

c One inhibitor unit (1 IU) is difined as the amount of inhibitor which suppressed liberation of one $\mu$ mol $p$ nitroaniline per min by active enzymes. 


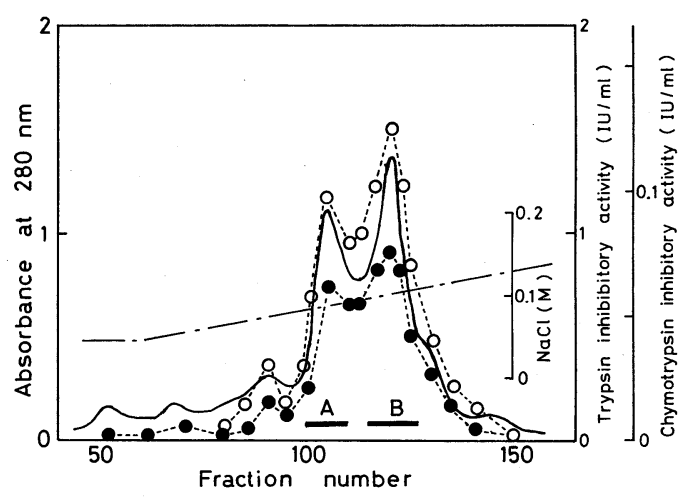

Fig. 2. DEAE-Toyopearl Column Chromatography of Peak I.

Details are described in the text. Flow rate, $40 \mathrm{ml} / \mathrm{hr}$ and fraction volume, $8 \mathrm{ml}$ : The symbols are the same as in Fig. 1.

was dissolved in $0.05 \mathrm{M}$ Tris- $\mathrm{HCl}$ buffer, $\mathrm{pH}$ 8.0 , containing $0.05 \mathrm{M} \mathrm{NaCl}$ and put on a DEAE-Toyopearl column $(1.8 \times 60 \mathrm{~cm})$ equilibrated with the same buffer. The column was eluted with a linearly increasing concentration of $\mathrm{NaCl}$ from 0.05 to $0.15 \mathrm{M}(800 \mathrm{ml}$ each) in the same buffer (Fig. 2). Two major peaks appeared and both of the components inhibited trypsin and chymotrypsin. They were separately pooled, dialyzed, lyophilized, and designated as OTI-A for the first peak and as OTI-B for the second peak. The yields of OTI$A$ and OTI-B were $64 \mathrm{mg}$ and $99 \mathrm{mg}$, respectively. Each of them was purified more by rechromatography on DEAE-Toyopearl under the same conditions. The yields of rechromatographed OTI-A and OTI-B were $36 \mathrm{mg}$ and $72 \mathrm{mg}$, respectively.

The lyophilized sample of peak II (255 mg) was put on a CM-Sepharose CL-6B column $(3.5 \times 30 \mathrm{~cm})$ equilibrated with $0.1 \mathrm{M}$ acetate buffer, pH 4.0 (Fig. 3), and eluted with a pH gradient formed from 1 liter each of $0.1 \mathrm{M}$ acetate buffers, $\mathrm{pH} 4.0$ and 5.7. As shown in Fig. 3, proteins appeared as two major peaks with inhibitory activity. They were named peak $\mathrm{D}$ for the former and peak $\mathrm{C}$ for the latter because the elution position of the two peaks was reversed in the DEAE-cellulose column chromatography. ${ }^{3)}$ Peak D inhibited trypsin

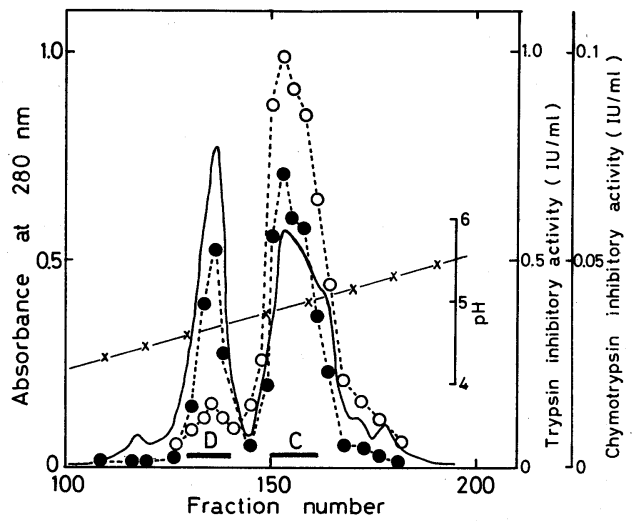

Fig. 3. CM-Sepharose CL-6B Column Chromatography of Peak II.

Peak II ( $255 \mathrm{mg}$ ) was dissolved in $30 \mathrm{ml}$ of $0.1 \mathrm{M}$ acetic acid, $\mathrm{pH}$ 2.9. After removal of insoluble materials by centrifugation, the supernatant was put on a CM-Sepharose column $(3.5 \times 30 \mathrm{~cm})$ equilibrated with $0.1 \mathrm{M}$ acetate buffer, $\mathrm{pH}$ 4.0. Elution was done with a $\mathrm{pH}$ gradient formed from 1 liter each of $0.1 \mathrm{~m}$ acetate buffers, $\mathrm{pH} 4.0$ and 5.7. Flow rate, $40 \mathrm{ml} / \mathrm{hr}$ and fraction volume, $10 \mathrm{ml}$. The symbols are the same as in Fig. 1. $-\times-, \mathrm{pH}$.

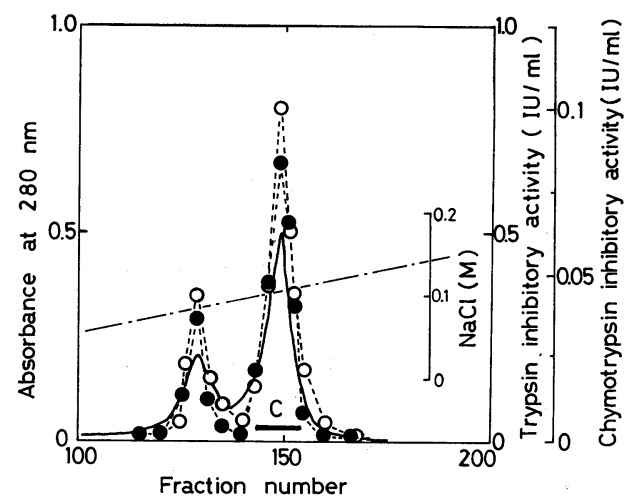

FIG. 4. DEAE-Toyopearl Column Chromatography of Peak C.

Peak C ( $34 \mathrm{mg}$ ) was dissolved in $0.05 \mathrm{~m}$ phosphate buffer, $\mathrm{pH} 6.5$, and put on a DEAE-Toyopearl column $(1.4 \times$ $60 \mathrm{~cm}$ ) equilibrated with the same buffer. The column was developed with a linear gradient formed from zero to $0.2 \mathrm{M}$ of $\mathrm{NaCl}$ in the same buffer. Flow rate, $40 \mathrm{ml} / \mathrm{hr}$ and fraction volume, $6 \mathrm{ml}$. The symbols are the same as in Fig. 1.

but not chymotrypsin and was almost homogeneous by polyacrylamide gel electrophoresis (Fig. 5). Therefore, peak D fractions indicated by the bar in Fig. 3 were pooled, dialyzed, lyophilized, and named OTI-D $(35 \mathrm{mg})$. The 
unsymmetrical peak $\mathrm{C}$ was further purified by chromatography on DEAE-Toyopearl.

The lyophilized peak $\mathrm{C}$ fraction $(34 \mathrm{mg}$ ) was dissolved in $0.05 \mathrm{~m}$ phosphate buffer, $\mathrm{pH} 6.5$, and put on a DEAE-Toyopearl column $(1.4 \times 60 \mathrm{~cm})$ equilibrated with the same buffer (Fig. 4). Proteins appeared as two peaks, a minor peak and a main symmetrical peak, and both peaks inhibited trypsin and chymotrypsin. The latter main peak was designated as OTI-C. After dialysis and lyophilization, the yield of OTI-C was $14 \mathrm{mg}$. The minor peak was not purified further, although it contained some components which inhibited trypsin and chymotrypsin.

\section{Homogeneity of the purified inhibitors}

Each of the purified inhibitors was contaminated by minute amounts of electrophoretically distinguishable components on an analytical polyacrylamide gel in the presence or absence of SDS (Fig. 5).

\section{Molecular weights}

The molecular weights of the four inhibitors were all estimated to be approximately 20,000 by SDS-polyacrylamide gel electrophoresis and also by gel filtration on a Sephadex G-100 column. The results of SDS-polyacrylamide gel electrophoresis in the presence of a reducing agent suggested that all inhibitors were composed of a single polypeptide chain.

\section{Isoelectric points and hexose contents}

The isoelectric points were estimated to be $\mathrm{pH} 4.7$ for OTI-A, 4.6 for OTI-B, 4.3 for OTI$\mathrm{C}$, and 4.2 for OTI-D by gel electrofocusing.

Hexose in the inhibitors was measured by the phenol-sulfuric acid method. ${ }^{25)}$ OTI-A, OTI-B, OTI-C, and OTI-D contained $1.6 \%$, $1.4 \%, \quad 3.9 \%$, and $0.7 \%$ hexose $(\mathrm{w} / \mathrm{w})$, respectively.

\section{Stability}

On standing at room temperature, the inhibitors were stable throughout the $\mathrm{pH}$ range of 2 to 12. After incubating the inhibitors in buffers, $\mathrm{pH} 3$ and $\mathrm{pH} 8$, for $10 \mathrm{~min}$ at various
(A)

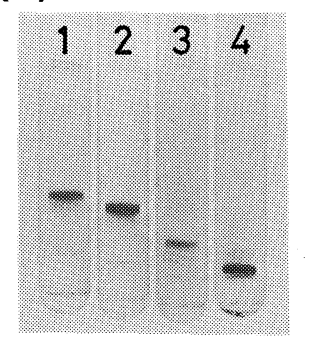

(B)

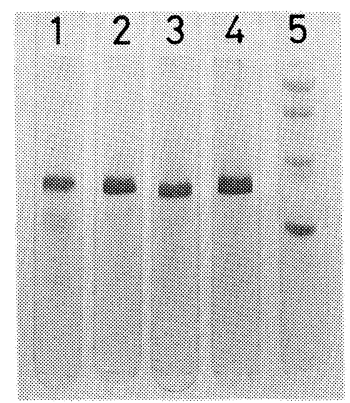

FIG. 5. Polyacrylamide Gel Electrophoresis of the Purified Inhibitors.

(A) Polyacrylamide gel electrophoresis in $7.5 \%$ gels, $\mathrm{pH}$ 9.4. The four inhibitors ( $30 \mu \mathrm{g}$ each) were electrophoresed at a current of $2 \mathrm{~mA}$ per gel. (b) SDS-polyacrylamide gel electrophoresis in $14 \%$ gels. Protein samples were treated with $1 \%$ SDS in the presence of $5 \% 2$-mercaptoethanol and electrophoresed at a current of $8 \mathrm{~mA}$ per gel for $6 \mathrm{hr}$. 1, OTI-A; 2, OTI-B; 3, OTI-C; 4, OTI-D; 5, standard proteins, from top to bottom, bovine serum albumin $(66,000)$; ovalbumin $(45,000)$; chymotrypsinogen $(25,000)$; cytochrome $c(12,400)$.

temperatures, they were stable up to about $60^{\circ} \mathrm{C}$ but they were rapidly inactivated at $80^{\circ} \mathrm{C}$.

\section{Amino acid compositions}

In Table II the amino acid compositions of the four inhibitors are summarized. These inhibitors contained more tryptophan than the inhibitors from legume seeds such as soybean $^{26)}$ and winged bean. ${ }^{27)}$ The half-cystine contents were 6 residues per molecule for all inhibitors. No free sulfhydryl groups were detected by the method of Ellman, ${ }^{21)}$ so all half-cystine residues appear to be in the form of disulfide bonds.

\section{Amino-terminal residue}

The amino-terminal residue was analyzed by the dansylation method. Only dansyl-alanine was detected by polyamide layer chromatography. All inhibitors have alanine as the amino-terminal residue.

\section{Inhibition of proteases}

When the inhibitory activities of the purified 
Table II. Amino Acid Compositions of the PURIFIED OKRA TRYPSIN INHIBITORS

Values are molar ratios with respect to glutamic acid and the values of parentheses are the nearest integers.

\begin{tabular}{|c|c|c|c|c|}
\hline \multirow{2}{*}{ Amino acid } & \multicolumn{4}{|c|}{ Residues per molecule } \\
\hline & OTI-A & OTI-B & OTI-C & OTI-D \\
\hline Asp & $22.3(22)$ & $17.2(17)$ & $23.2(23)$ & $21.4(21)$ \\
\hline $\operatorname{Thr}^{a}$ & $7.2(7)$ & $6.4(6)$ & 8.5 ( 9) & $6.9(7)$ \\
\hline $\operatorname{Ser}^{a}$ & $15.3(16)$ & $16.7(17)$ & $16.4(17)$ & $19.5(20)$ \\
\hline Glu & $14.0(14)$ & $17.0(17)$ & $16.0(16)$ & $14.0(14)$ \\
\hline Pro & $10.2(10)$ & $10.3(10)$ & $7.3(7)$ & $10.2(10)$ \\
\hline Gly & $20.8(21)$ & $22.8(23)$ & $22.3(22)$ & $21.4(21)$ \\
\hline Ala & $9.2(9)$ & $10.9(11)$ & $9.8(10)$ & $9.3(9)$ \\
\hline $1 / 2 \mathrm{Cys}^{b}$ & $5.6(6)$ & $5.5(6)$ & $5.7(6)$ & $5.9(6)$ \\
\hline Val & $19.7(20)$ & 18.9 (19) & $21.2(21)$ & $21.6(22)$ \\
\hline Met & $2.8(3)$ & $2.6(3)$ & $3.2(3)$ & $2.6(3)$ \\
\hline Ile & $4.8(5)$ & $6.1(6)$ & $4.4(5)$ & $7.3(7)$ \\
\hline Leu & $8.2(8)$ & $9.1(9)$ & $9.5(10)$ & 10.9 (11) \\
\hline Tyr & $4.6(5)$ & $3.7(4)$ & $2.8(3)$ & $3.9(4)$ \\
\hline Phe & $5.8(6)$ & $6.3(6)$ & $5.0(5)$ & $5.6(6)$ \\
\hline Lys & $11.9(12)$ & $8.3(8)$ & $6.5(7)$ & $6.9(7)$ \\
\hline His & $1.8(2)$ & $1.0(1)$ & $0.8(1)$ & $1.2(1)$ \\
\hline Arg & $9.7(10)$ & $10.3(10)$ & 9.4 ( 9$)$ & $6.6(7)$ \\
\hline $\operatorname{Trp}^{c}$ & $7.1(7)$ & $5.7(6)$ & $10.1(10)$ & 9.3 (9) \\
\hline Total & 183 & 179 & 185 & 186 \\
\hline
\end{tabular}

a Values of $24 \mathrm{hr}$ hydrolysates.

Measured as cysteic acid. ${ }^{19)}$

Measured spectrophotometrically. ${ }^{20)}$

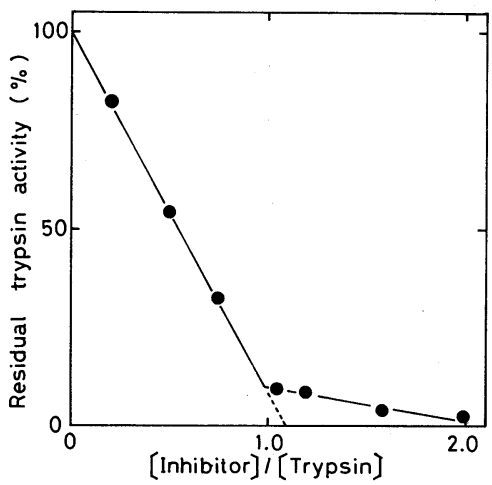

FIG. 6. Titration of Bovine Trypsin with OTI-C.

Fixed amount of trypsin $\left(1.8 \times 10^{-7} \mathrm{M}\right)$ was titrated with increasing amounts of OTI-C at $\mathrm{pH}$ 8.0. BAPA was used as a substrate for trypsin.

inhibitors toward several proteases were tested, these inhibitors had no effect on porcine pepsin, papain, subtilisin, or pronase. The four inhibitors inhibited trypsin strongly and stoi-
TABle III. Inhibitor Constants of the Four OKRA TRYPSIN INHIBITORS

\begin{tabular}{ccc}
\hline \multirow{2}{*}{ Inhibitor } & \multicolumn{2}{c}{ Inhibitor constant $(\mathrm{Ki})$} \\
\cline { 2 - 3 } & $\operatorname{Trypsin}^{a}$ & Chymotrypsin $^{b}$ \\
\hline OTI-A & $7.3 \times 10^{-9} \mathrm{M}$ & $5.4 \times 10^{-7} \mathrm{M}$ \\
OTI-B & $1.5 \times 10^{-9} \mathrm{M}$ & $2.1 \times 10^{-7} \mathrm{M}$ \\
OTI-C & $2.4 \times 10^{-10} \mathrm{M}$ & $9.6 \times 10^{-8} \mathrm{M}$ \\
OTI-D & $2.7 \times 10^{-9} \mathrm{M}$ & $\mathrm{ND}^{c}$ \\
\hline
\end{tabular}

a Calculated by the method of Green and Work. ${ }^{17)}$

$b$ Calculated by the method of Dixon. ${ }^{18)}$

c ND, not determined.

chiometrically. A representative titration curve of trypsin with OTI-C is shown in Fig. 6. All of the four inhibitors reacted with trypsin at a molar ratio of $1: 1$. Three of the four inhibitors (OTI-A, OTI-B, and OTI-C) were weaker and nonstoichiometric inhibitors of chymotrypsin under the conditions we used but OTI-D did not inhibit the enzyme.

The inhibitor constants (Ki's) of each inhibitor toward trypsin and chymotrypsin calculated by the methods of Green and Work ${ }^{17)}$ and Dixon ${ }^{18)}$ are shown in the Table III.

\section{Gel filtration of trypsin-OTI complex}

When a mixture of trypsin and an excess of molar equivalent OTI (each of OTI-A, OTI-B, and OTI-C) was filtered on a Sephadex G-100 gel column, two major protein peaks appeared (Fig. 7). The molecular weights of the first and second major peaks were about 43,000 and 20,000 , respectively. The 1:1 molar inhibitortrypsin complex which appeared as the first peak (MW 43,000) no longer inhibited either trypsin or chymotrypsin. The second major peak (MW 20,000) was that of excess inhibitor. The three inhibitors, OTI-A, OTI-B, and OTI$\mathrm{C}$, inhibited both the enzymes but not simultaneously.

\section{Modification of lysine and arginine residues}

The effects of CHD on the inhibitory activity of the four inhibitors are shown in Fig. 8. For OTI-A, the trypsin and chymotrypsin inhibition were similarly lost with time of incubation. For OTI-B, about $80 \%$ of the 


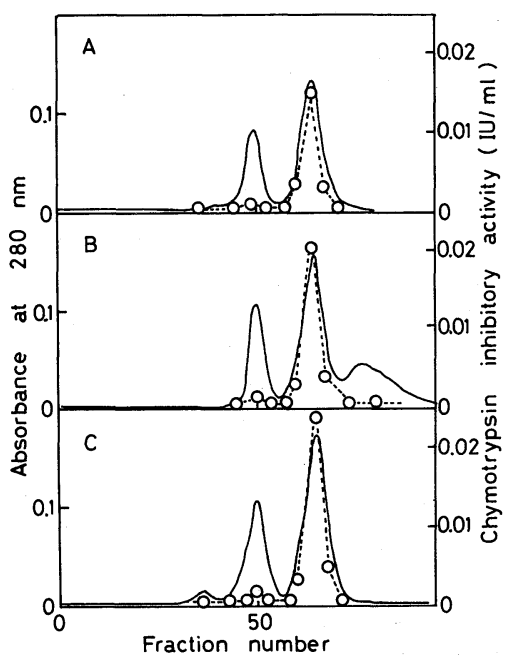

FIG. 7. Gel Filtration of the Inhibitor-Tyrpsin Complex.

Trypsin ( $1 \mathrm{mg}$ ) and $2 \mathrm{mg}$ each of OTI-A, OTI-B, and OTI$\mathrm{C}$ were dissolved in $1.0 \mathrm{ml}$ of $0.05 \mathrm{M}$ Tris- $\mathrm{HCl}$ buffer, $\mathrm{pH}$ 8.0 , containing $0.05 \mathrm{M} \mathrm{NaCl}$. After incubation for $5 \mathrm{~min}$ at room temperature, the mixture was put on a Sephadex G100 column $(1.4 \times 90 \mathrm{~cm})$ equilibrated with the same buffer. Flow rate, $13 \mathrm{ml} / \mathrm{hr}$ and fraction volume, $2 \mathrm{ml}$; - absorbance at $280 \mathrm{~nm}$; --- $\bigcirc---$, chymotrypsin inhibitory activity.
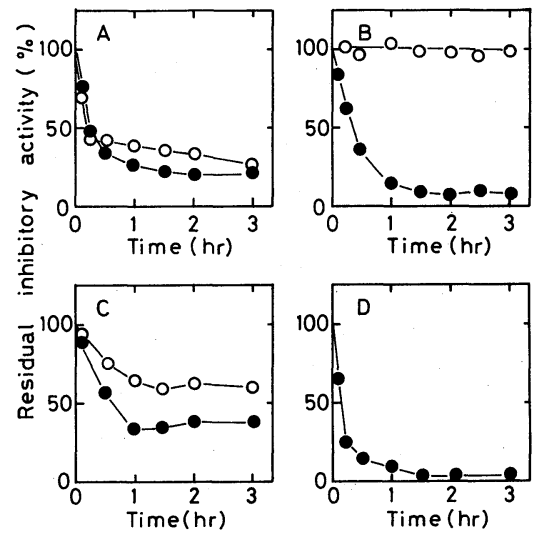

FIG. 8. Modification of Arginine Residues in the Inhibitors with CHD.

Experimental conditions are described in the text. trypsin inhibitory activity; $\bigcirc$, chymotrypsin inhibitory activity.

original trypsin inhibition was lost after $90 \mathrm{~min}$, while chymotrypsin inhibition remained without change. For OTI-C, the decrease of chymotrypsin inhibition was slower than that of trypsin inhibition. For OTI-D, after $1 \mathrm{hr}$ of incubation, almost all of the trypsin inhibition was lost. The trypsin inhibition of all the four OTI's was not suppressed by modification with 2,4,6-trinitrobenzenesulfonate (data not shown). We concluded that these inhibitors contain arginine residues in a reactive site toward trypsin. However, it is uncertain whether the reactive site against chymotrypsin of OTI-A and OTI-C contains arginine or not.

\section{DISCUSSION}

The four okra trypsin inhibitors have a molecular weight of about 20,000 and a low half-cystine content. In these respects the inhibitors resemble soybean trypsin inhibitor (Kunitz), ${ }^{26)}$ winged bean chymotrypsin inhibitor, ${ }^{27)}$ and silk tree inhibitor. ${ }^{28)}$ The legume seed inhibitors having high molecular weights generally contain two cystines, but the four inhibitors from okra contain three cystine residues. The difference in cystine content seems to reflect the botanical family specificities. Relatively high content of tryptophan is one of the unusual characteristics of the okra inhibitors.

To avoid the formation of so-called modified inhibitors, ${ }^{29)}$ the four inhibitors were purified by the usual procedure without the use of affinity chromatography. Therefore, the four inhibitors purified from okra seeds are isoinhibitors which have much the same molecular weight $(20,000)$, the identical aminoterminal amino acid, alanine, and closely related amino acid compositions (Table II). Distinct differences are observed in the values such as hexose content, isoelectric points, and inhibitor constants (see RESULTS).

The results of the titration experiments and the gel filtration of inhibitor-trypsin complex on Sephadex G-100 show that one molecule of these inhibitors could bind one molecule of trypsin. The inhibitor constants of the four inhibitors suggest that affinity of these inhibitors toward trypsin is stronger than that toward chymotrypsin. OTI-C showed the 
strongest affinity to trypsin and chymotrypsin among the four inhibitors.

The four inhibitors showed a variety of behaviors upon the chemical modification of arginine residues by $\mathrm{CHD}$. It is clear that one or more arginine residues of OTI-A participate in binding of this inhibitor with both trypsin and chymotrypsin. OTI-B appears to have two independent reactive sites, one for trypsin and the other for chymotrypsin, and this inhibitor has an arginine residue as the reactive site for trypsin. OTI-C appears to have two independent reactive sites for the two enzymes as OTI-B dose. However, approximately $40 \%$ of the chymotrypsin inhibitory activity of OTI-C was lost upon the modification of arginine residues. Therefore, the reactive site for chymotrypsin in OTI-C may be near an arginine residue. The arginine residue is almost certain to be the reactive site for trypsin of OTI-C. The independent reactive sites for trypsin and chymotrypsin of OTI-B or OTI-C may be very close to each other, because chymotrypsin was not inhibited by the inhibitor-trypsin complexes form OTI-B and OTI-C which were isolated by the gel filtration (Fig. 7). If the two reactive site are very far apart, the inhibitortrypsin complex could inhibit chymotrypsin through the formation of the ternary complex of chymotrypsin-inhibitor-trypsin. Further investigation is necessary to elucidate the interaction of two reactive site for the two enzymes with these inhibitors, especially the reactive site for chymotrypsin in these inhibitors.

The nutritional significance of okra trypsin inhibitors is still unclear. The inhibitors are presumably not antinutrients since they are relatively unstable over $80^{\circ} \mathrm{C}$ and have no effect toward porcine pepsin. The high protein efficiency ratio of okra seeds reported by Karakoltsidis and Constantinides also supports the above speculation. In our preliminary experiments, however, the trypsin inhibitory activity was detected in the unmatured seeds of eatable young pods. When the young raw pods are eaten by animals, it is unclear at present if the inhibitors act as antinutrients or not.

The physiological function of protease inhibitors in the plant is not clear. The protease inhibitors in seeds or tubers may exist as stored proteins that will play a role in germination. Therefore the stored protein may be present in a stable form against attack of proteases of invaders, insects, and microorganisms.

\section{REFERENCES}

1) T. C. I. E. Cooke, "The Flora of the Presidency of Bombay," Vol. I, Botanical Survey of India, Calcutta, 1958, p. 119.

2) P. A. Karakoltsidis and S. M. Constantinides, $J$. Agric. Food Chem., 23, 1204 (1975).

3) F. Ogata, Y. Morioka and S. Makisumi, Mem. Fac. Sci., Kyushu Univ., Ser. C., 14, 165 (1983).

4) T. Chase, Jr. and E. Shaw, "Methods in Enzymology," Vol. XIX, ed. by G. E. Perlmann and L. Lorand, Academic Press Inc., New York, 1970, p. 20.

5) D. T. Elmore and J. J. Smith, Biochem. J., 107, 103 (1968).

6) F. Ogata and S. Makisumi, J. Biochem., 96, 1565 (1984).

7) B. Kassell, "Methods in Enzymology," Vol. XIX, ed. by G. E. Perlmann and L. Lorand, Academic Press Inc., New York, 1970, p. 840.

8) B. Hagihara, H. Matsubara, M. Nakai and K. Okunuki, J. Biochem., 45, 185 (1958).

9) R. Arnon, "Methods in Enzymology," Vol. XIX, ed. by G. E. Perlmann and L. Lorand, Academic Press Inc., New York, 1970, p. 226.

10) Y. Narahashi, "Methods in Enzymology," Vol. XIX, ed. by G. E. Perlmann and L. Lorand, Academic Press Inc., New York, 1970, p. 651.

11) J. Tang, "Methods in Enzymology," Vol. XIX, ed. by G. E. Perlmann and L. Lorand, Academic Press Inc., New York, 1970, p. 406.

12) O. H. Lowry, N. J. Rosebrough, A. L. Farr and R. J. Randall, J. Biol. Chem., 193, 265 (1951).

13) B. J. Davis, Ann. N. Y. Acad. Sci., 121, 404 (1964).

14) K. Weber and M. Osborn, J. Biol. Chem., 244, 4406 (1969).

15) C. W. Wrighley, "Methods in Enzymology," Vol. XXII, ed. by W. B. Jacoby, Academic Press Inc., New York, 1971, p. 559.

16) M. Dubois, K. A. Gilles, J. K. Hamilton, P. A. Rebers and F. Smith, Anal. Chem., 28, 350 (1956).

17) N. Y. Green and E. Work, Biochem. J., 54, 347 (1953).

18) M. Dixon, Biochem. J., 55, 170 (1953).

19) S. Moore, J. Biol. Chem., 238, 235 (1963).

20) H. Edelhoch, Biochemistry, 7, 1948 (1967). 
21) G. L. Ellman, Arch. Biochem. Biophys., 82, 70 (1959).

22) W. R. Gray, "Methods in Enzymology," Vol. XXV, ed. by C. W. Hirs and S. N. Timasheff, Academic Press Inc., New York, 1972, p. 121.

23) K. R. Woods and K. T. Wang, Biochim. Biophys. Acta, 133, 369 (1967).

24) L. Patthy and E. L. Smith, J. Biol. Chem., 50, 557 (1975).

25) B. V. Plapp, S. Moore and W. H. Stein, J. Biol.
Chem., 246, 939 (1971).

26) T. Koide and T. Ikenaka, Eur. J. Biochem., 23, 401 (1973).

27) A. A. Kortt, Biochim. Biophys. Acta, 624, 237 (1980).

28) S. Odani, T. Ono and T. Ikenaka, J. Biochem., 80, 1795 (1979).

29) M. Laskowski, Jr. and R. W. Sealock, "The Enzymes," Vol. III, ed. by P. D. Boyer, Academic Press Inc., New York-London, 1971, p. 376. 